\title{
Glucose metabolism by preimplantation pig embryos
}

\author{
M. R. Flood and J. L. Wiebold \\ Department of Animal Sciences, Washington State University, Pullman, Washington 99164, U.S.A.
}

\begin{abstract}
Summary. Pig embryos were collected, 2-7 days after oestrus, in modified BMOC-2 containing glucose as the only energy source. Embryos were incubated individually in medium containing $\left[5-{ }^{3} \mathrm{H}\right]-,\left[1-{ }^{14} \mathrm{C}\right]-$ or $\left[6-{ }^{14} \mathrm{C}\right]$ glucose. Total glucose metabolism, as measured by $\left[5-{ }^{3} \mathrm{H}\right]$ glucose use, increased steadily from the 1-cell to the 8-cell stage. Total glucose use increased $(P<0.05)$ at the compacted morula stage and was highest $(P<0.05)$ at the blastocyst stage. Production of ${ }^{14} \mathrm{CO}_{2}$ from embryos metabolizing $\left[1-{ }^{14} \mathrm{C}\right]$ glucose increased steadily from the unfertilized ovum to the 8-cell stage. Metabolism of $\left[1-{ }^{14} \mathrm{C}\right]$ glucose increased at the compacted morula stage $(P<0.05)$ and continued to increase $(P<0.05)$ to the blastocyst stage. Metabolism of $\left[6-{ }^{14} \mathrm{C}\right] \mathrm{glucose}$ increased steadily from the unfertilized ovum to the compacted morula stage. Metabolism of $\left[6-{ }^{14} \mathrm{C}\right]$ glucose was highest $(P<0.05)$ for the blastocyst stage. Percentage pentose phosphate pathway activity of total glucose metabolism before the 4-cell stage was higher $(>5 \%)$ than that of 8 -cell to blastocyst stage embryos $(\sim 1 \%)$. When embryo metabolism was determined on a per cell basis for each isotope, the compacted morulae stage ( 16 cells) had a higher total glucose metabolism than all other embryo stages $(P<0 \cdot 05)$, while early blastocyst ( 32 cells) and blastocyst ( 64 cells) stage embryos metabolized more $\left[5-{ }^{3} \mathrm{H}\right]$ glucose than all stages except compacted morulae $(P<0.05)$. Metabolism of $\left[1-{ }^{14} \mathrm{C}\right]$ glucose was highest for 1 -cell embryos $(P<0.05)$, while there were no differences in $\left[6-{ }^{14} \mathrm{C}\right]$ glucose metabolism among stages of development $(P>0.05)$ on a per cell basis. The results indicate that glucose is not being metabolized readily by pig embryos before the 8-cell stage and glucose is utilized in higher amounts in embryos between the compacted morula and blastocyst stages. This is the first report of glucose metabolism and determination of pentose phosphate pathway activity in pig embryos.
\end{abstract}

Keywords: embryo; embryo culture; embryonic mortality; glucose metabolism; pig

\section{Introduction}

The insertion of new nuclear material into mammalian embryos has become common (Palmiter et al., 1983; Willadsen, 1986). With the advent of these genetic engineering studies there is an increasing need for the culture of preimplantation embryos, and so the metabolic functions of mammalian embryos need to be assessed.

Most mammalian embryonic metabolism studies have been conducted using mouse embryos. The main reasons for this are that the first culture medium was developed for mouse embryos (Brinster, 1963) and a large number of embryos can be obtained at a relatively small cost per embryo. Early research in mouse embryo energy metabolism (see Brinster, 1973, for review) indicated that glucose metabolism was low until it increased markedly between the 8-cell and morula stages.

Extrapolation from mouse embryo metabolism to embryos from other species is possible because there are general developmental similarities in embryos of eutherian mammals. Brinster 
(1973) states that extrapolation of nutrient requirements and metabolism of mouse embryos to the embryos of large, economically important domestic species is valid. However, studies conducted with rabbit embryos indicate that glucose metabolism in this species does not increase dramatically until the blastocyst stage (Fridhandler, 1961), later than in mouse embryos. Therefore, if extrapolation from mouse embryo metabolism to rabbit embryo metabolism is not accurate, extrapolation to pig embryo metabolism may also not be valid.

O'Fallon \& Wright (1986) have developed a technique to measure glucose metabolism in single embryos. Embryos were recovered following the completed assay and upon transfer into recipient mice normal offspring were obtained. O'Fallon \& Wright (1986) also quantitatively determined pentose phosphate pathway activity for the first time in embryos. It is therefore now possible to determine glucose metabolism by using a small amount of biological material which is often limiting in the embryos of large domestic species.

The objectives of the present study were to measure total glucose metabolism and to determine pentose phosphate pathway activity of pig embryos at different preimplantation stages.

\section{Materials and Methods}

Embryo collection. Cross-bred pubertal gilts were used to obtain embryos for this study. The 50 animals were killed 2-7 days after the first detected oestrus and mating. Some animals were not mated so that unfertilized ova could be collected. Reproductive tracts were recovered and embryos were collected via an oviducal (2-3 days after oestrus) or uterine (3-7 days after oestrus) flush. The amount of time from removal of the reproductive tract to flushing for embryos was less than $15 \mathrm{~min}$. Modified BMOC-2 (1.7 mM-CaCl $, 4.8 \mathrm{~mm}-\mathrm{KCl}, 1 \cdot 1 \mathrm{~mm}-\mathrm{KH}_{2} \mathrm{PO}_{4}, 1 \cdot 2 \mathrm{~mm}-\mathrm{MgSO}_{4}$, $130.0 \mathrm{~mm}-\mathrm{NaCl}, 0 \cdot 25 \% \mathrm{BSA}$; Brinster, 1963), containing $100 \mu \mathrm{M}$-glucose as the only energy source and $25 \mathrm{~mm}-\mathrm{Hepes}$ as a buffer, was the flushing medium. Embryo recovery rate was $78 \%$ ( 473 embryos $/ 610$ corpora lutea) and 61 of these embryos were considered to be degenerate, either at collection or after incubation, and were not included in the results. Embryos were rinsed 3 times in flushing medium to remove debris and reduce the possibility of contamination during incubation.

Determination of morphological stages of development. Spermatozoa in the zona pellucida and the presence of a second polar body were the criteria for an embryo to be classified in the 1-cell stage of development. Lack of spermatozoa in the zona pellucida and an absence of second polar body extrusion indicated an unfertilized ovum. Embryos at the 2-8-cell stages were morphologically easy to distinguish. Embryos were considered to be at the compacted morula stage if the cells inside the zona pellucida were not individually distinguishable and appeared to be compacting. Early blastocyst stage embryos were those which had a blastocoele cavity that did not fill the entire space inside the zona. Blastocyst stage embryos were those embryos in which the blastocoele cavity filled the entire space inside the zona. Embryos were classified as degenerate at collection if they appeared morphologically abnormal (i.e. extruded or degenerate cells). Embryos were classified as degenerate after incubation if they had not developed one stage further than when placed in culture.

Embryo incubation. Embryos were placed into incubation chambers as described by O'Fallon \& Wright (1986), with slight modification. A single embryo was drawn into a micropipette with $1 \mu$ l flushing medium and placed on the lid of the incubation chamber with another $2 \mu \mathrm{l}$ flushing medium containing $0.06 \mu \mathrm{Ci}$ of radioactively labelled glucose. The incubation chambers were kept at $37^{\circ} \mathrm{C}$ in $5 \% \mathrm{CO}_{2}$ in air. The metabolism of $\left.\left[5-{ }^{3} \mathrm{H}\right] \mathrm{g}\right]$ ucose, $\left[1-{ }^{14} \mathrm{C}\right] \mathrm{glucose}$ and $\left[6-{ }^{14} \mathrm{C}\right]$ glucose was linear from 1 to $6 \mathrm{~h}$ in blastocysts (data not shown). A 4-h incubation period was chosen for these experiments. Embryos were recovered from the lid of each incubation chamber after the 4-h incubation period and placed separately into $70 \mu \mathrm{l}$ drops of Whitten's medium (Whitten \& Biggers, 1968) under paraffin oil in sterile Petri dishes. Each embryo was examined immediately after the 4-h incubation period and once daily for 7 days. Only embryos which developed one stage further than when placed in the incubation chamber were included in the results. The bottom portion of the incubation chamber, which contained $0 \cdot 1 \mathrm{~N}-\mathrm{NaOH}$ as a trap for ${ }^{3} \mathrm{H}_{2} \mathrm{O}$ or ${ }^{14} \mathrm{CO}_{2}$, was mixed with $10 \mathrm{ml}$ Aqueous Counting Solution (Amersham Corporation, Arlington Heights, IL) following the 4-h incubation period and counted for $5 \mathrm{~min}$ in a liquid scintillation spectrophotometer to determine metabolism of the radioactive glucose.

Materials. Bovine serum albumin (crystalline) and Hepes ( $n$-2-hydroxy-ethyl-piperazine- $N$-ethanesulphonic acid) were obtained from Sigma Chemical Company (St Louis, MO). D-[5- $\left.{ }^{3} \mathrm{H}\right] \mathrm{Glucose}$ (sp. act. 15.7 Ci/mmol) was obtained from Amersham Corporation (Arlington Heights, IL). D- $\left[1-{ }^{14} \mathrm{C}\right] \mathrm{Glucose}$ (sp. act. $50 \mathrm{mCi} / \mathrm{mmol}$ ) and $\mathrm{D}-\left[6^{-14} \mathrm{C}\right] \mathrm{glucose}$ (sp. act. $45 \mathrm{mCi} / \mathrm{mmol}$ ) were obtained from Research Products International Corporation (Mount Prospect, IL).

Calculations and statistical analysis. Total glucose metabolism via the glycolytic and pentose phosphate pathways was determined by $\left[5-{ }^{3} \mathrm{H}\right]$ glucose utilization, as measured by ${ }^{3} \mathrm{H}_{2} \mathrm{O}$ production. The metabolism of $\left[1-{ }^{14} \mathrm{C}\right] \mathrm{glucose}$ and $\left[6-{ }^{14} \mathrm{C}\right]$ glucose was measured by the production of ${ }^{14} \mathrm{CO}_{2}$. The metabolism of labelled glucose was expressed as 
$\mathrm{pmol} / \mathrm{embryo} / 4-\mathrm{h}$ and pmol/cell/4-h. Compacted morulae were assumed to contain 16 cells, early blastocysts 32 cells and blastocysts 64 cells, based on a 24-h cell cycle and research which reports similar numbers for these cell stages (Davis \& Day, 1978; Niemann et al., 1982).

Pentose phosphate pathway activity was determined by the calculations given by O'Fallon \& Wright (1986) using the information from $\left[55^{3} \mathrm{H}\right]-,\left[1-{ }^{14} \mathrm{C}\right]-$, and $\left[6-{ }^{14} \mathrm{C}\right]$ glucose metabolism for each embryo stage. Activity is expressed as percentage of total glucose metabolism as calculated from specific yields of $\mathrm{CO}_{2}$.

Differences in metabolism of embryo stages for each isotope were analysed on a per cell basis and per embryo basis by using the general linear models procedure of the Statistical Analysis System (SAS Institute Inc., 1985). Analysis was based on a nested design using gilts within stage as the nested factor and embryos within gilts as the subsample. Duncan's range test was conducted when there were significant stage differences.

\section{Results}

Total glucose metabolism (Table 1) in pig embryos, as measured by $\left[5-{ }^{3} \mathrm{H}\right]$ glucose utilization, increased steadily from the 1-cell to the 8-cell stage but differences between the stages were not statistically significant $(P>0.05)$. Glucose metabolism increased $(P<0.05)$ at the compacted morula stage and continued to increase to the blastocyst stage $(P<0.05)$. When metabolism was determined on a per cell basis there was also a significant stage effect on total glucose metabolism $(P<0.01)$. Compacted morulae had higher total glucose metabolism than did all other embryo stages $(P<0.05)$ and early blastocysts and blastocysts metabolized $\left[5-{ }^{3} \mathrm{H}\right] \mathrm{glucose}$ at a higher level $(P<0.05)$ than all embryo stages except the compacted morula. There tended $(P<0.07)$ to be a gilt-within-stage effect for this isotope.

Table 1. Metabolism of glucose by preimplantation pig embryos

\begin{tabular}{|c|c|c|c|c|c|}
\hline \multirow[b]{2}{*}{ Glucose } & \multirow[b]{2}{*}{ Stage } & \multirow[b]{2}{*}{$\begin{array}{l}\text { No. of } \\
\text { donors }\end{array}$} & \multirow[b]{2}{*}{$\begin{array}{c}\text { No. of } \\
\text { embryos }\end{array}$} & \multicolumn{2}{|c|}{ Glucose metabolism } \\
\hline & & & & $\begin{array}{c}\text { pmol/embryo/4-h } \\
\text { (mean } \pm \text { s.e.m.) }\end{array}$ & $\begin{array}{c}\mathrm{pmol} / \mathrm{cell} / 4-\mathrm{h} \\
(\text { mean) }\end{array}$ \\
\hline \multirow[t]{8}{*}[5-{}^{3}\mathbf{H}]{-} & Unfertilized & 3 & 10 & $0.4 \pm 0 \cdot 1^{\mathrm{a}}$ & $0.4^{a}$ \\
\hline & $1-$ cell & 3 & 13 & $0 \cdot 4 \pm 0 \cdot 1^{a}$ & $0 \cdot 4^{a}$ \\
\hline & 2-cell & 3 & 12 & $0 \cdot 6 \pm 0 \cdot 1^{2}$ & $0 \cdot 3^{\mathrm{a}}$ \\
\hline & 4-cell & 6 & 36 & $0.9 \pm 0 \cdot 1^{\mathrm{a}}$ & $0 \cdot 2^{\mathrm{a}}$ \\
\hline & 8-cell & 3 & 13 & $3 \cdot 1 \pm 0.4^{a}$ & $0 \cdot 4^{a}$ \\
\hline & Compacted morula & 3 & 10 & $49 \cdot 5 \pm 2.7^{b}$ & $3 \cdot 1^{\mathrm{b}}$ \\
\hline & Early blastocyst & 3 & 9 & $69 \cdot 8 \pm 2 \cdot 0^{\mathrm{c}}$ & $2 \cdot 2^{\mathrm{c}}$ \\
\hline & Blastocyst & 3 & 15 & $147 \cdot 0 \pm 12 \cdot 0^{\mathrm{d}}$ & $2 \cdot 3^{c}$ \\
\hline \multirow[t]{8}{*}[1-{}^{14}\mathrm{C}]{-} & Unfertilized & 3 & 8 & $0 \cdot 1 \pm 0 \cdot 1^{\mathrm{a}}$ & $0 \cdot 1^{\mathbf{a}}$ \\
\hline & 1 -cell & 4 & 11 & $0.4 \pm 0.1^{\mathrm{a}}$ & $0.4^{\mathrm{b}}$ \\
\hline & 2-cell & 4 & 16 & $0.5 \pm 0 \cdot 1^{a}$ & $0 \cdot 2^{\mathrm{a}}$ \\
\hline & 4-cell & 3 & 15 & $0.7 \pm 0.2^{\mathrm{a}}$ & $0 \cdot 2^{\mathrm{a}}$ \\
\hline & 8-cell & 6 & 20 & $0.7 \pm 0.2^{\mathrm{a}}$ & $0 \cdot 1^{\mathrm{a}}$ \\
\hline & Compacted morula & 5 & 9 & $2 \cdot 0 \pm 0.4^{\mathrm{b}}$ & $0 \cdot 1^{\mathrm{a}}$ \\
\hline & Early blastocyst & 3 & 9 & $4.2 \pm 0.6^{\mathrm{c}}$ & $0 \cdot 1^{\mathrm{a}}$ \\
\hline & Blastocyst & 3 & 4 & $7 \cdot 9 \pm 2 \cdot 0^{\mathrm{d}}$ & $0 \cdot 1^{2}$ \\
\hline \multirow[t]{8}{*}[6-{}^{14}\mathrm{C}]{-} & Unfertilized & 4 & 9 & $0 \cdot 1 \pm 0 \cdot 1^{\mathrm{a}}$ & $0 \cdot 10^{\mathrm{ac}}$ \\
\hline & $1-$ cell & 4 & 7 & $0.3 \pm 0.1^{\mathrm{ab}}$ & $0 \cdot 30^{\mathrm{b}}$ \\
\hline & 2-cell & 3 & 5 & $0.3 \pm 0.2^{\mathrm{ab}}$ & $0 \cdot 18^{\mathrm{ab}}$ \\
\hline & 4-cell & 6 & 21 & $0.6 \pm 0.1^{\mathrm{ab}}$ & $0 \cdot 14^{\mathrm{ac}}$ \\
\hline & 8-cell & 7 & 30 & $0.6 \pm 0.1^{2 b}$ & $0 \cdot 11^{\text {ac }}$ \\
\hline & Compacted morula & 6 & 11 & $0.8 \pm 0.3^{\mathrm{bc}}$ & $0.05^{\mathrm{c}}$ \\
\hline & Early blastocyst & 3 & 6 & $1 \cdot 2 \pm 0.3^{c}$ & $0.04^{\mathrm{c}}$ \\
\hline & Blastocyst & 3 & 5 & $2.5 \pm 0.7^{\mathrm{d}}$ & $0.04^{\mathrm{c}}$ \\
\hline
\end{tabular}

Means with different letters are significantly different $(P<0.05)$. 
Metabolism of $\left[1-{ }^{14} \mathrm{C}\right]$ glucose (Table 1) is a measure of pentose phosphate pathway, glycolysis and tricarboxylic acid cycle activity. As measured by ${ }^{14} \mathrm{CO}_{2}$ production, $\left[1-{ }^{14} \mathrm{C}\right]$ glucose metabolism was similar between 1 -cell and 8 -cell embryos $(P>0.05)$, but increased in compacted morulae and continued to increase to the blastocyst stage $(P<0.05)$. Stage also tended to affect metabolism of $\left[1-{ }^{14} \mathrm{C}\right]$ glucose $(P<0.07)$ when the results were placed on a per cell basis: values for the 1-cell stage were higher than those for all other embryo stages $(P<0.05)$. There was a significant gilt-within-stage effect $(P<0 \cdot 01)$ for the metabolism of $\left[1-{ }^{14} \mathrm{C}\right] \mathrm{glucose}$.

Metabolism of $\left[6-{ }^{14} \mathrm{C}\right]$ glucose (Table 1) is a measure of glycolytic and tricarboxylic acid cycle activity. The metabolism of $\left[6-{ }^{14} \mathrm{C}\right]$ glucose steadily increased but not significantly $(P>0.05)$ from the 1-cell to the 8-cell stage. Metabolism of $\left[6-{ }^{14} \mathrm{C}\right]$ glucose was highest at the blastocyst stage $(P<0.05)$. On a per cell basis, there was a significant stage effect on metabolism $(P<0.05)$ : values for 1 -cell embryos were higher $(P<0.05)$ than for unfertilized ova and decreased to the blastocyst stage. There was a significant gilt-within-stage effect $(P<0 \cdot 05)$ for the metabolism of $\left[6-{ }^{14} \mathrm{C}\right]$ glucose.

Percentage activity of the pentose phosphate pathway was relatively low $(1 \%)$ from the 8-cell to the blastocyst stage. Embryos at the 4-cell stage had an intermediate activity (9\%), while 1-cell and 2-cell embryos had higher activity (53 and 44\%, respectively). Unfertilized oocytes had intermediate activity $(5 \%)$.

\section{Discussion}

Total glucose metabolism of pig embryos as measured by ${ }^{3} \mathrm{H}_{2} \mathrm{O}$ production from $\left[5-{ }^{3} \mathrm{H}\right]$ glucose was low but started to increase beginning at the compacted morula stage, the same as for $\left[{ }^{14} \mathrm{C}\right] \mathrm{glucose}$ metabolism in mouse embryos (Biggers et al., 1967; Brinster, 1967). Mouse embryos at the blastocyst stage metabolize $\left[5-{ }^{3} \mathrm{H}\right]$ glucose at a level 10 -fold higher than at the 2-cell stage (O'Fallon \& Wright, 1986) while pig embryos increased glucose metabolism by approximately 300 -fold between these stages. Therefore, total glucose metabolism of pig embryos at later stages is much higher than that reported for mouse embryos, but the results also suggest that pig embryos do metabolize glucose in a pattern similar to that of mouse embryos, as proposed by Brinster (1973).

However, when values of $\left[5-{ }^{3} \mathrm{H}\right]$ glucose metabolism for mouse and pig embryos are compared, mouse embryos metabolize more glucose than do pig embryos until the compacted morula stage. The techniques in this study were modified slightly from those reported by O'Fallon \& Wright (1986) and this may be the reason for the lower values in pig embryos. The flushing solution contained $100 \mu \mathrm{M}$ unlabelled glucose in this experiment, while it was not mentioned whether any unlabelled glucose was added in the mouse experiment. The addition of unlabelled glucose lowered the specific activity of the radiolabelled isotopes to ensure that the embryo would not be affected by the 4-h incubation period. In addition, the BSA used in this experiment was crystallized and lyophilized while the BSA used by O'Fallon \& Wright (1986) was not. The BSA (or a contaminant bound to it) used in the mouse experiment might have activated embryos to metabolize more glucose than did the BSA used in this pig study. Kane (1983) has shown that there are considerable differences between lots of BSA in their ability to affect embryonic cell divisions.

Tight junctions are formed between the outermost cells of the 8-cell embryo during compaction (Davenport, 1979). This starts the determination process of the inner cell mass and trophoblastic cells (Johnson et al., 1977). The formation of these junctions may require more energy, or other substances produced from glucose, and so an increase in glucose metabolism at this stage would be necessary. This may help to explain the fact that the compacted morula has a higher total glucose metabolism than all other stages, on a per cell basis.

The early blastocyst and blastocyst metabolize, on a per cell basis, lower total glucose levels than does the compacted morula, but the metabolism is higher than for pig embryos before the 8-cell stage. The formation and expansion of the blastocoele may require high amounts of energy, and this energy increase may be produced in part by metabolism of high amounts of glucose. 
The gilt effect, which was seen to some extent with all three labelled compounds, could be due to differences in times after ovulation when gilts were killed. Ovulation time could not be accurately determined in this experiment.

The activity of the pentose phosphate pathway in preimplantation pig embryos is high in the 1-cell and decreases steadily to the 8-cell stage, in which activity is the same as that for all embryo stages up to the blastocyst stage. Mouse embryos have an activity ranging from $3 \%$ at the blastocyst stage up to $15 \%$ at the 2-cell stage (O'Fallon \& Wright, 1986). Pentose phosphate pathway activity is therefore higher in early stages and less in later stages of pig embryos, when compared to mouse embryos.

From these results, it is clear that much of the glucose metabolism by pig embryos before the 8-cell stage is via the pentose phosphate pathway, and from the 8-cell to blastocyst stage glucose metabolism is almost exclusively via the glycolytic pathway. A possible cause of this sudden increase in glycolytic pathway activity may be an increase in hexokinase activity, which is known to be present in mouse embryos (Barbehenn et al., 1974). The amount of glucose 6-phosphate could be low in the embryo because of low hexokinase activity and, when glucose 6-phosphate levels increase, then the activity of other enzymes in the glycolytic pathway could be increased (Barbehenn et al., 1974). Also, hexokinase could be active but there may not be high enough glucose levels in the embryo to allow adequate phosphorylation to glucose 6-phosphate. However, the uptake of glucose into various stages of pig embryos has not been reported. Another possible cause of the sudden increase in glycolytic activity may be an increase in phosphofructokinase activity which is inhibited by high ATP concentrations; ATP levels fall by $35-60 \%$ between the 2-cell and early blastocyst stage in mouse embryos (Quinn \& Wales, 1971). The falling ATP values reported for mouse embryos may also occur in pig embryos. The levels of ATP and the content or activity of phosphofructokinase and hexokinase have not been investigated in pig embryos. Such information and increased knowledge of metabolic processes of the pig embryo should lead to improved media for in-vitro culture.

Early embryonic death is a major cause of reduced litter size in the pig industry and Bazer $e t$ al. (1982) and Bazer \& Roberts (1983) have suggested that there is an essential factor which is lacking or limiting in the uterus which leads to early embryonic death. The present results suggest that glucose is important as an energy source for later stage preimplantation pig embryos.

We thank Dr Raymond Wright, Jr and Dr Joe Hillers for serving on the thesis committee for M.F.; Dr James O'Fallon for invaluable advice; Alan Aldrich and Dean Peters at the Swine Center and Duncan Dunn at the Meats Laboratory; and Jim Selgrath and Lori Been for technical assistance. Scientific Paper No. 7806, College of Agriculture and Home Economics Research Center, Washington State University, Project No. 0593.

\section{References}

Barbehenn, E.K., Wales, R.G. \& Lowry, O.H. (1974) The explanation for the blockade of glycolysis in early mouse embryos. Proc. natn. Acad. Sci., U.S.A. 71, $1056-1060$.

Bazer, F.W. \& Roberts, R.M. (1983) Biochemical aspects of conceptus-endometrial interactions. J. exp. Zool. 228, 373-377.

Bazer, F.W., Geisert, R.D., Thatcher, W.W. \& Roberts, R.M. (1982) The establishment and maintenance of pregnancy. In Control of Reproduction in the Pig, pp. 227-246. Eds D. J. A. Cole \& G. R. Foxcroft. Butterworths, London.

Biggers, J.D., Whittingham, D.G. \& Donahue, R.P. (1967) The pattern of energy metabolism in the mouse embryo and zygote. Proc. natn. Acad. Sci.,
U.S.A. 58, 560-567.

Brinster, R.L. (1963) A method for in vitro cultivation of mouse ova from the two-cell to blastocyst. Expl Cell Res. 32, 205-208.

Brinster, R.L. (1967) Carbon dioxide production from glucose by the preimplantation mouse embryo. Expl Cell Res. 47, 271-277.

Brinster, R.L. (1973) Nutrition and metabolism of the ovum, zygote and blastocyst. In Handbook of Physiology, Vol. 2, pp. 165-170. Eds R. O. Greep, E. B. Astwood \& S. R. Geiger. Am. Physiol. Soc., Washington, D.C.

Davenport, R. (1979) An Outline of Animal Development, pp. 311-326. Addison-Wesley Publishing Co. Inc., Menlo Park. 
Davis, D.L. \& Day, B.N. (1978) Cleavage and blastocyst formation by pig eggs in vitro. J. Anim. Sci. 46, 1043-1053.

Fridhandler, L. (1961) Pathways of glucose metabolism in fertilized rabbit ova at various pre-implantation stages. Expl Cell Res. 22, 303-316.

Johnson, M.H., Handyside, A.H. \& Braude, P.R. (1977) Control mechanisms in early mammalian development. In Development in Mammals, Vol. 2, pp. 67-98. Ed. M. H. Johnson. North-Holland, Amsterdam.

Kane, M.T. (1983) Variability in different lots of commercial bovine serum albumin affects cell multiplication and hatching of rabbit blastocysts in culture. J. Reprod. Fert. 69, 555-558.

Niemann, H., Illera, M.J. \& Dziuk, P.J. (1982) Developmental capacity, size and number of nuclei in pig embryos cultured in vitro. Anim. Reprod. Sci. 5, 311-321.
O'Fallon, J.V. \& Wright, R.W., Jr (1986) Quantitative determination of the pentose phosphate pathway in preimplantation mouse embryos. Biol. Reprod. 34, 58-64.

Palmiter, R.D., Norstedt, G., Gelinas, R.E., Hammer, R.E. \& Brinster, R.L. (1983) Metallothionein-human GH fusion genes stimulate growth of mice. Science, N.Y. 222, 809-814.

Quinn, P. \& Wales, R.G. (1971) Adenosine triphosphate content of preimplantation mouse embryos. $J$. Reprod. Fert. 25, 133-135.

SAS Institute, Inc. (1985) SAS User's Guide: Statistics, Version 5 Edition, pp. 433-507. SAS Institute, Cary.

Whitten, W.K. \& Biggers, J.D. (1968) Complete development in vitro of the preimplantation stages of the mouse in a simple chemically defined medium. $J$. Reprod. Fert. 17, 399-402.

Willadsen, S.M. (1986) Nuclear transplantation in sheep embryos. Nature, Lond. 320, 63-65.

Received 7 August 1987 